DOI: $10.7242 / 2658-705 X / 2019.1 .1$

УДК 579.61: 579.842.11: 574.24

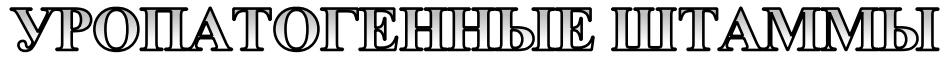

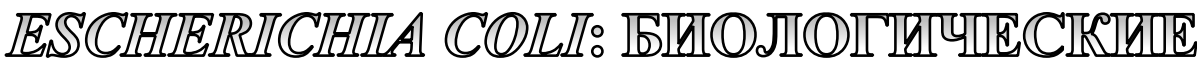

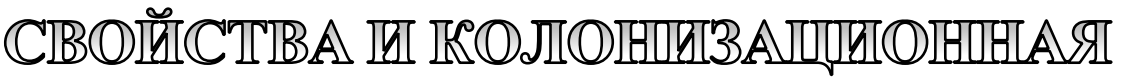 ATKTIGIBIHIOCTIB *
}

М.В. Кузнецова, Институт экологии и генетики микроорганизмов УрО РАН

Ю.С. Гизатуллина, Институт экологии и генетики микроорганизмов УрО РАН

В.А. Демаков, Институт экологии и генетики микроорганизмов УрО РАН

Проблема катетер-ассоциированных инфекций мочевыводящих путей обусловлена активным заселением бактериями внедренных в организм медицинских материалов и формированием на них биопленок. Представлена характеристика уринарных и катетер-ассоциированных нозокомиальных штаммов уропатогенной Escherichia coli (UPEC). Изучены биопленкообразование и выживаемость UPEC на различных типах урологических катетеров в монокультуре и в ассоциациях in vitro. Показано влияние свойств атакуемой поверхности и факторов внешней среды на колонизационную активность бактерий.

Ключевые слова: уропатогенные Escherichia coli, биопленки, урологические катетеры, микробные ассоциаичии.

Биопленки как форма существования микроорганизмов привлекают все большее внимание в последние годы. Особо актуальной эта тема является для медицинской микробиологии в связи с широким применением в клинической практике био- и искусственных материалов, поверхности которых активно колонизируются бактериями [10]. Известно, что в составе биопленки клетки лучше защищены от негативных факторов. Экзополисахаридный матрикс, продуцируемый бактериями, обеспечивает «экранирование» живых клеток от воздействия температуры, солей, УФ-излучения, токсичных веществ, антибактериальных препаратов и эффекторов иммунитета $[9,15]$. Высокая степень защиты бактерий способствует их длительному сохранению, повышает риск персистенции возбудителя в организме и развития хронической инфекции $[1,5]$, поэтому биопленко-ассоциированные инфекции сложнее поддаются диагностике и лечению. Изучение механизмов формирования хронических инфекционных процессов и разработка способов борьбы с ними - одни из самых актуальных задач современной клинической микробиологии и инфектологии.

Наибольшее число случаев инфекций мочевыводящих путей (ИМВП) связано с катетер-ассоциированными инфекциями $[8,11]$, которые относятся к наиболее распространенным заболеваниям среди взрослого населения как в амбула-

\footnotetext{
* Работа выполнена в рамках государственного задания, номер госрегистрации темы: 01201353249.
} 
ИССЛЕДОВАНИЯ: ТЕОРИЯ И ЭКСПЕРИМЕНТ

торной, так и в стационарной практике во всем мире $[3,16]$. Ведущая роль в развитии данной группы болезней отводитcя Escherichia coli (кишечной палочке) в монокультуре или в составе ассоциаций. Штаммы, вызывающие ИМВП уропатогенные E. coli (UPEC) - имеют ряд особенностей, обусловливающих повышенную выживаемость бактерий в мочевыделительном тракте. Они способны закрепляться на поверхности уротелия, вырабатывать блокаторы местного иммунного ответа организма, формировать слизистые капсулы, обеспечивающие дополнительную защиту $[1,7,13,17]$. Для понимания механизмов адаптации бактерий к условиям уротракта активно изучаются биологические свойства штаммов E. coli, выделенных при осложненных, в том числе катетеризацией, формах заболеваний.

\section{Характеристики уропатогенной $\boldsymbol{E}$. coli}

В проспективном двухгодичном исследовании из бактериологических лабораторий г. Перми было получено 93 штамма UPEC от пациентов, находящихся на стационарном лечении с ИМВП. Из них 73 культуры были выделены из мочи, 20 получены непосредственно с поверхности уринарных катетеров через 48 ч после госпитализации [6].

Использование мультиплексной ПЦР (quadriplex PCR) согласно Clermont и соавт. (2013) позволило определить филогенетическую группу более чем 90\% штаммов UPEC. Нозокомиальные культуры почти в 88,2\% случаев принадлежали к филогруппе В2, к которой отнесены и все катетер-ассоциированные штаммы (табл.).

Анализ биопленкообразующей способности UPEC показал, что она варьировалась в широких пределах: от 0,054 до 0,593 ед. ОП570. Распределив штаммы по степени биопленкообразования

Сравнительная характеристика биологических свойств штаммов UPEC, выделенных из мочи и с поверхности катетеров

\begin{tabular}{|c|c|c|}
\hline Признак & $\begin{array}{c}\text { Уринарные } \\
\text { штаммы } \\
(\mathrm{n} / \%)\end{array}$ & $\begin{array}{c}\text { Катетер- } \\
\text { ассоциированные } \\
\text { штаммы (n/\%) }\end{array}$ \\
\hline \multicolumn{3}{|c|}{ Филогруппа: } \\
\hline B2 & $62 / 84,9$ & $20 / 100$ \\
\hline $\mathrm{He}$ B2 & $11 / 8,03$ & 0 \\
\hline \multicolumn{3}{|c|}{ Гемолиз } \\
\hline с гемолизом & $15 / 20,5$ & $4 / 20,0$ \\
\hline \multicolumn{3}{|c|}{ Биопленкоформирование: } \\
\hline Низкое & $21 / 28,8$ & $11 / 55,0^{*}$ \\
\hline Высокое & $52 / 71,2$ & $9 / 45,0$ \\
\hline \multicolumn{3}{|c|}{ Антибиотикорезистентность: } \\
\hline Ампициллин & $41 / 56,2$ & $12 / 60,0$ \\
\hline Амоксициллин & $18 / 24,7$ & $11 / 55,0^{*}$ \\
\hline Цефотаксим & $27 / 37,0$ & $12 / 60,0$ \\
\hline Амикацин & $6 / 8,2$ & $2 / 10,0$ \\
\hline Ципрофрлоксацин & $25 / 34,2$ & $12 / 60,0^{*}$ \\
\hline Продукция БЛРС & $17 / 23,3$ & $12 / 60,0^{*}$ \\
\hline
\end{tabular}

(более 0,3 ед. ОП 570 - высокое биопленкообразование, менее 0,3 ед. ОП $570-$ низкое биопленкообразование), выявили, что 65,6\% формировали массивную биопленку, при этом биопленкообразующими чаще были уринарные E. coli, чем катетерассоциированные культуры. Гемолитическую активность проявляли только $20 \%$ исследованных UPEC, и их доля не различалась между группами. Важно отметить, что штаммы, выделенные при катетеризации, чаще были устойчивы к амоксициллину и ципрофлоксацину. Продукция бета-лактамаз расширенного спектра (БЛРС) была выявлена у двадцати девяти $(31,2 \%)$ культур, при этом статистически значимо их доля различалась в группах нозокомиальных штаммов: уринарные < катетер-ассоциированные $(\mathrm{p}<0,005)$. Таким образом, наши результаты согласуются с данными исследований, которые указывают на возможность концентрирования в стационаре E. coli филогруппы В2, а представители именно этой группы считаются основными патогенами для человека. 


\section{Влияние условий среды} на биопленкообразующую способность уропатогенной $\boldsymbol{E}$. coli

Большинство ИМВП вызваны представителями нескольких видов фекальной микробиоты $[12,20]$. Хорошо известна способность таких микроорганизмов, как Pseudomonas aeruginosa, Klebsiella pneumoniae, Staphylococcus aureus, изменять $\mathrm{pH}$ окружающей среды биотопа, продуцируя уреазу - фермент, расщепляющий мочевину с образованием свободного аммиака $[5,24]$. Изменение уровня кислотности играет большую роль в жизнеспособности бактериальных клеток и развитии инфекционного процесса. В литературе встречаются противоречивые данные о влиянии $\mathrm{pH}$ среды на биопленкообразование эшерихий, тогда как оптимум роста E.coli находится в диапазоне $\mathrm{pH}$ 6,0-8,0 [22,23]. Поскольку именно этот микроорганизм является ведущим этиопатогеном при ИМВП, интересно было оценить его «ответ» на изменение уровня кислотности среды.

Максимальная биомасса биопленок штаммов UPEC была зарегистрирована в диапазоне $\mathrm{pH} \mathrm{6,0-7,0.} \mathrm{При} \mathrm{этом} \mathrm{био-}$ пленкообразующая способность бактерий не различалась в слабокислой и слабощелочной среде и оставалась значительно ниже, чем при нейтральном уровне кислотности (рис. 1, А).

Содержание глюкозы в среде также является важным фактором, определяющим эффективность размножения бактерий. Известно, что у людей с сахарным диабетом выше риск развития ИМВП изза повышенной концентрации глюкозы в моче $[11,18,19]$. В нашем исследовании при увеличении количества основного питательного субстрата клетки E. coli образовывали более массивные биопленки, что хорошо видно на рис. 1, Б. Таким образом, показано, что более массивные биопленки были сформированы на поли-

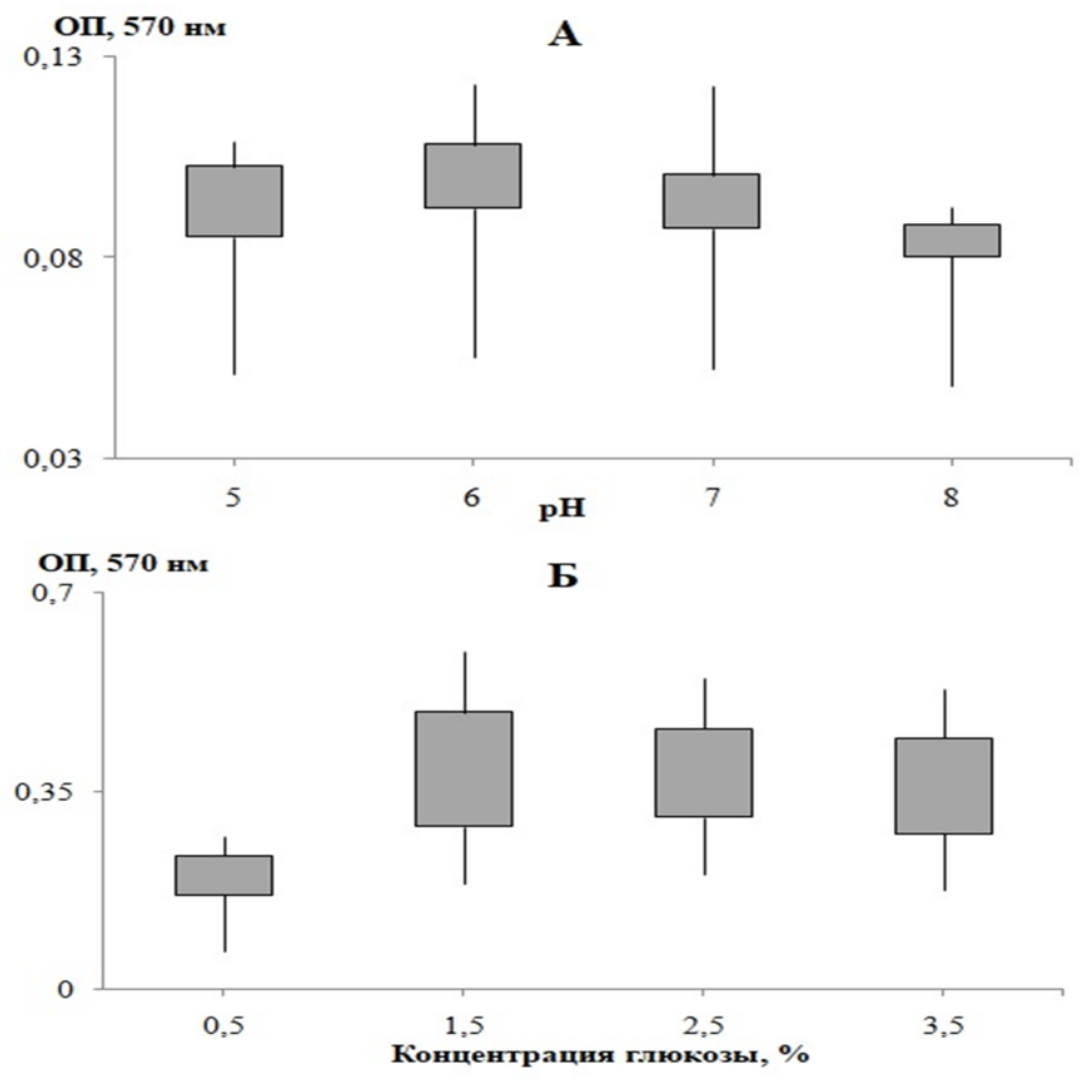

Рис. 1. Зависимость биомассы биопленки E. coli от уровня кислотности среды (А) и количества глюкозы (Б) 
стироле при концентрации глюкозы $1,5 \%$ и выше, а также при рН 6,0 и 7,0. В связи с последним можно предположить, что при смешанной инфекции E. coli будет иметь меньшее преимущество в росте, если ассоциант способен изменять $\mathrm{pH}$ среды.

\section{Модели для изучения процесса формирования биопленок}

Изучением биопленок в последние годы активно занимаются во всем мире. Несмотря на разнообразие целей исследований, основная работа осуществляется в модели, принятой в качестве классического образца - полистироловом иммунологическом планшете. Удобство данного варианта очевидно, так как в ходе эксперимента большинство параметров унифицированы (площадь поверхности, материал, кислородные условия и т.д.). Однако в случае клинической задачи по изучению биопленок полистироловый планшет может быть использован только для проведения предварительных исследований биологических свойств микроорганизмов.

Для получения более достоверных результатов по адгезивной, биопленко- образующей активности и выживаемости бактерий при моделировании катетер-ассоциированной инфекции необходимо использовать непосредственно применяемые в урологической практике материалы, которые различаются по многим показателям (архитектура поверхности, гидрофобность и шероховатость, поверхностный заряд, наличие дополнительных антимикробных агентов и т.д.).

Самыми распространенными на сегодняшний день являются катетеры Нелатона и Фолея из латекса, силикона, предназначенные для длительной катетеризации (более 7 дней), и поливинилхлорида (ПВХ). Среди вышеперечисленных типов катетеров есть много модификаций: гидрофильное покрытие, пропитка антибактериальными препаратами, напыление наночастиц серебра и др. Некоторые из них были использованы нами для изучения колонизационной активности UPEC (рис. 2).

\section{Колонизационная активность штаммов UPEC}

Используемые в современной практике урологические катетеры имеют различные показатели гидрофобности.
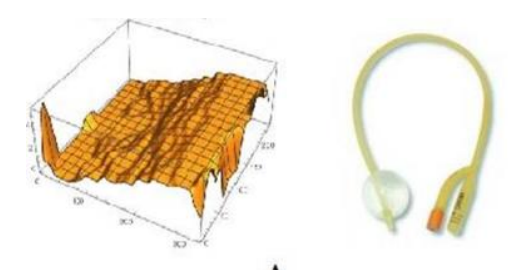

A
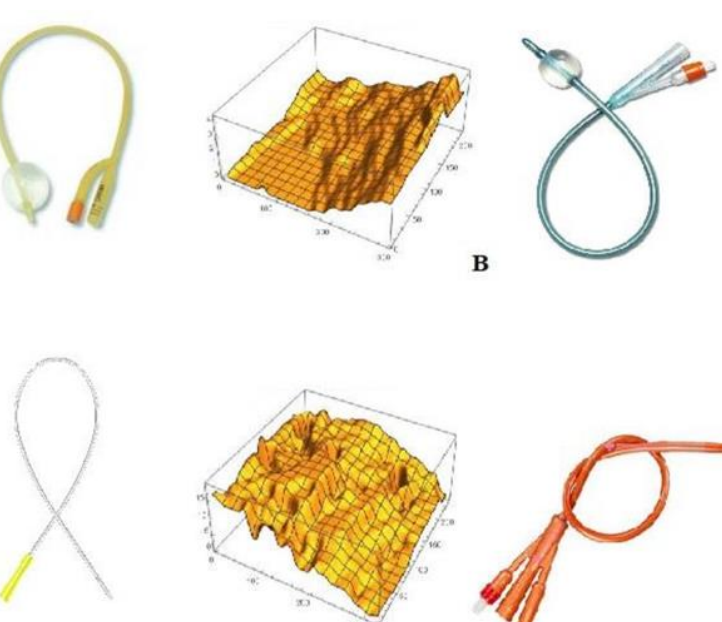

Б
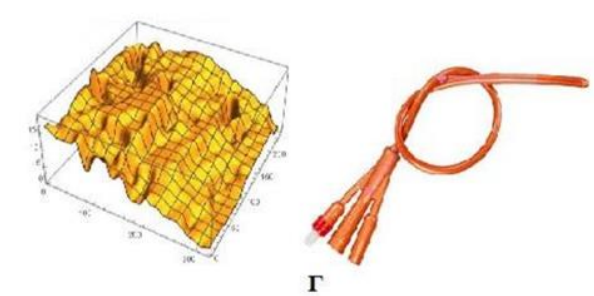

Pис. 2. Внешний вид (фотографии с сайта http://www.apexтеd.ru) и 3D-рельеф поверхности (получень с использованием оптического ичирового

3D-видеомикроскопа Hirox КН-7700 с.н.с. ИТХ УрО РАН Морозовым И.А.) урологических катетеров, применяемых в современной практике: $A$-латекс,

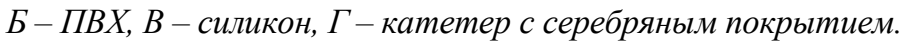


Ранее показано, что повышение гидрофильности материала препятствует биопленкообразованию микроорганизмов $[10,21]$. Согласно нашим исследованиям, наиболее гидрофобным является латексный катетер, а наименее - катетер из силикона. Полистирол в классической модели оказался самым гидрофобным в ряду абиотических поверхностей. Сильная корреляция $(\mathrm{Rs}=0,69)$ между показателем биомассы биопленки и гидрофобностью поверхности урологического катетера (рис. 3, А) доказывает, что физико-химические параметры материала определяют характер адгезии уропатогенных E. coli [2].
Наибольшее клиническое значение имеет количество жизнеспособных клеток, заключенных в биопленке, которая является резервуаром бактерий, способных к персистированию в организме. Для данного показателя можно проследить обратную зависимость: на катетере с наименьшей биопленкой (и самой низкой гидрофобностью, соответственно) наблюдалась самая высокая выживаемость клеток и наоборот (рис. 3, Б). При этом в полистироловом планшете, несмотря на высокий показатель гидрофобности и массивную биопленку, обнаружено большое число живых клеток. Полученные результаты подтверждают необходимость

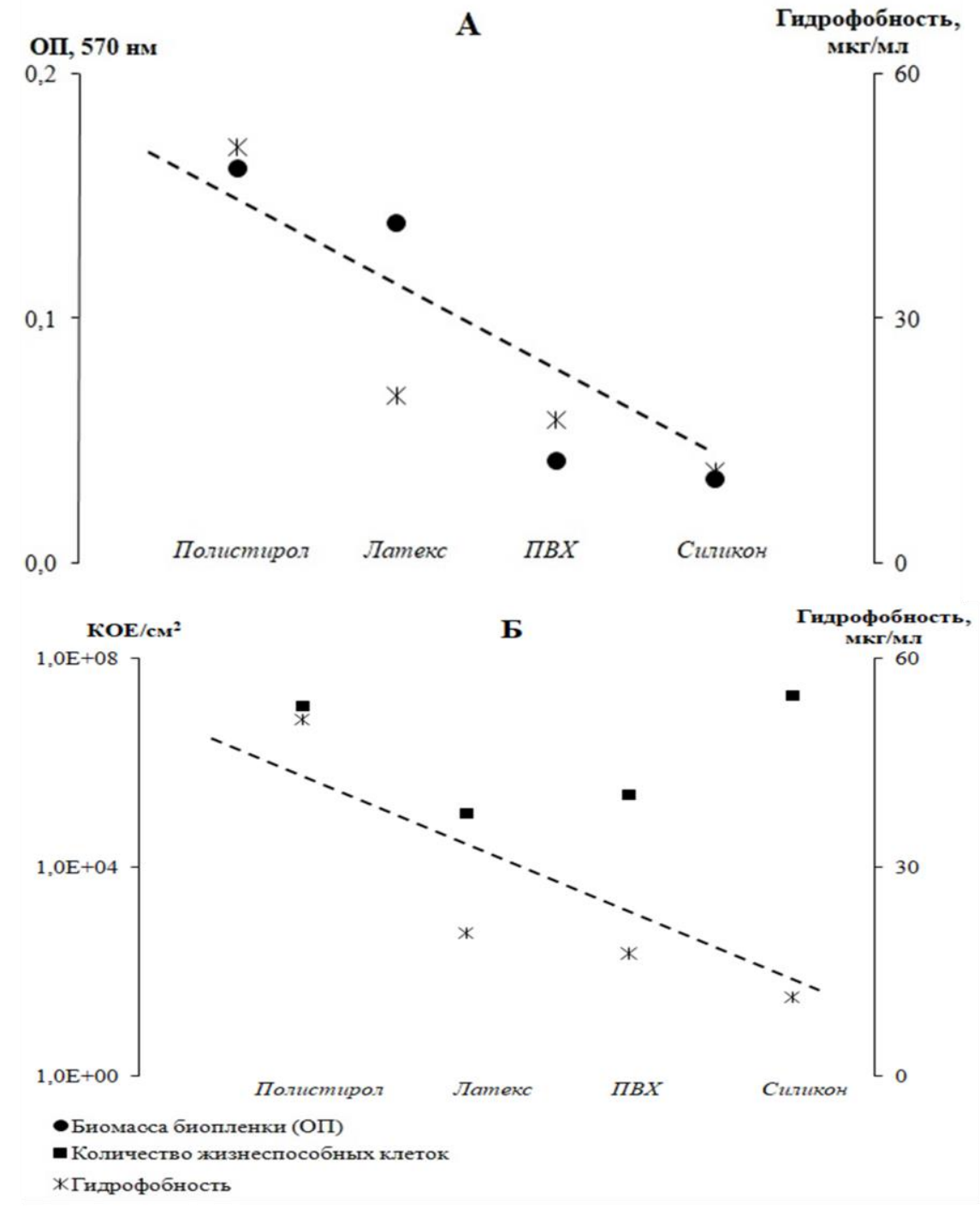

Рис. 3. Биомасса биопленок (А) и количество жизнеспособных клеток

E. coli (Б) на различных поверхностях. Пунктирная линия-усредненные значения гидрофобности поверхностей 
использования реальных материалов для изучения процесса колонизации в медицинских исследованиях.

\section{Смешанные инфекции мочевыводящих путей}

Наряду с ведущим этиопатогеном (E. coli - до 80\%) при ИМВП часто обнаруживаются K. pneumoniae, P. aeruginosa и Enterococcus faecalis [14, 20]. Ранее показано, что доля ассоциаций в уринарной группе составила 43,8\%, а в катетерассоциированной частота микст-вариантов выявлялась уже в 80\% исследований. Преобладающими при неосложненных [6] ИМВП были двухкомпонентные ассоциации $(78,1 \%)$, при катетеризации - двух-, трех- и четырехкомпонентные ассоциации встречались в равной степени (рис. 4).

Сравнение нозокомиальных UPEC, выделенных при ИМВП из мочи и с поверхности катетера, показало, что при катетеризации видовой спектр ассоциантов ограничен несколькими таксонами: клебсиелла, протей, неферментирующие бактерии (рис. 5), тогда как при неосложненных ИМВП изолированы коринебактерии, стрептококки, кандиды, которые вообще не были обнаружены при катетер-ассоциированных инфекциях. Интересно, что ассоциация E. coli-E. coli чаще встречалась в группе уринарных штаммов, изолированных у пациентов без катетеризации.

В связи с этим нами были изучены две наиболее часто встречающиеся микробные ассоциации - E. coli c K. pneumoniae и E. faecalis. При совместном росте эшерихий с клебсиеллой или энтерококком $\mathrm{pH}$ среды смещался в щелочную сторону до 8,5 с $K$.pneumoniae и 8,4 с E.faecalis, по сравнению с моновариантом E. coli (pH 7,5). Интересно, что в предварительных экспериментах на полистироле при нейтральной реакции среды монокультура E. coli имела более высокую биопленкообразующую способность, чем при $\mathrm{pH}$ 8,0 [4], a в ассоциациях, напротив, биомасса смешанной биопленки была выше.

При анализе двух наиболее распространенных урологических катетеров (латексного и силиконового) можно увидеть, что биомасса обеих смешанных биопленок была намного выше на поверхности латексного катетера, что согласуется с концепцией о влиянии гидрофобности материала на биопленкообразо-

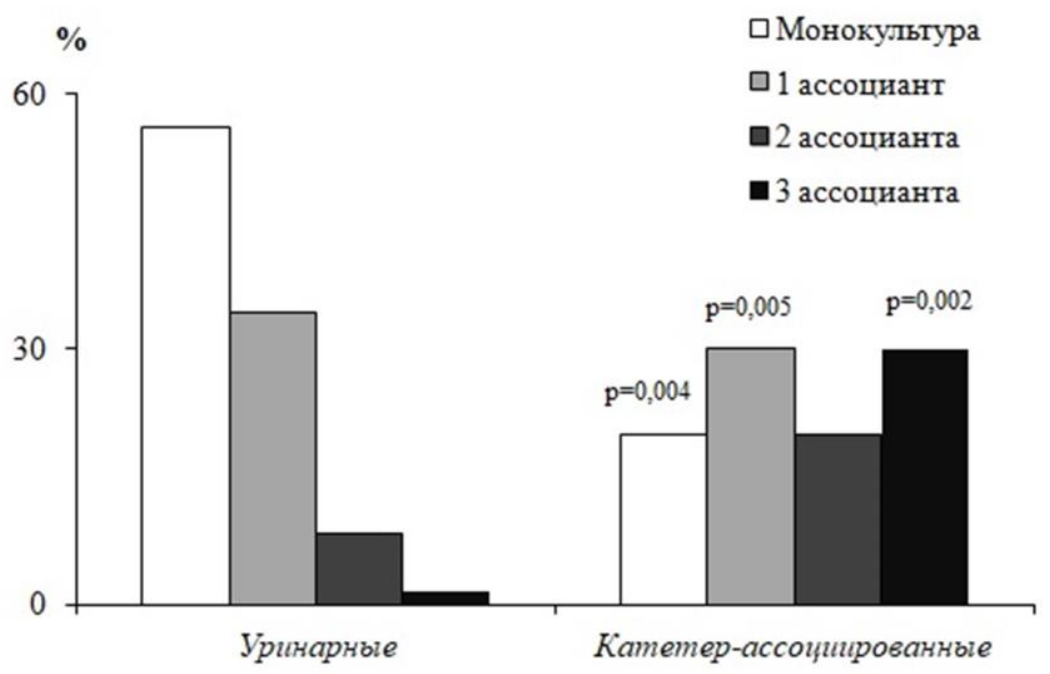

Pис. 4. Проиентное соотношение E. coli в монокультуре и в составе ассочиаций в моче и на поверхности катетеров. *p - уровень достоверности различий по сравнению с группой уринарных итаммов 


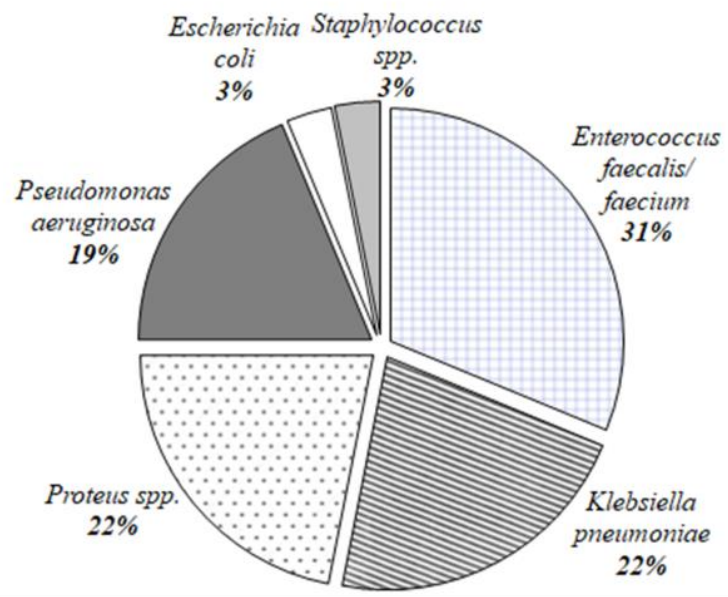

Puc. 5. Доли основных ассочиантов E. coli при катетер-ассоциированных инфекциях

вание (рис. 6). Также на его поверхности E. faecalis оказался практически не конкурентоспособным при совместном росте. K. pneumoniae, напротив, имела равное соотношение жизнеспособных клеток c E. coli на обеих поверхностях.

Таким образом, в модельном эксперименте было показано, что изменение условий роста при смешанных инфекциях (в частности уровня $\mathrm{pH}$ ) не имеет значительного влияния на рост клеток UPEC, которые обладают высокой конкурентоспособностью в ассоциациях как с грамотрицательными, так и с грампо- ложительными бактериями, что подтверждает их ведущую роль в инфекциях мочевыводящих путей.

\section{Заключение}

Штаммы уропатогенной E. coli имеют высокий потенциал для существования в условиях мочевыделительного тракта. Активность процесса биопленкообразования, выживаемость клеток на поверхности различных катетеров зависят от характеристик используемого материала, условий развития инфекции, а также видового разнообразия возбуди-

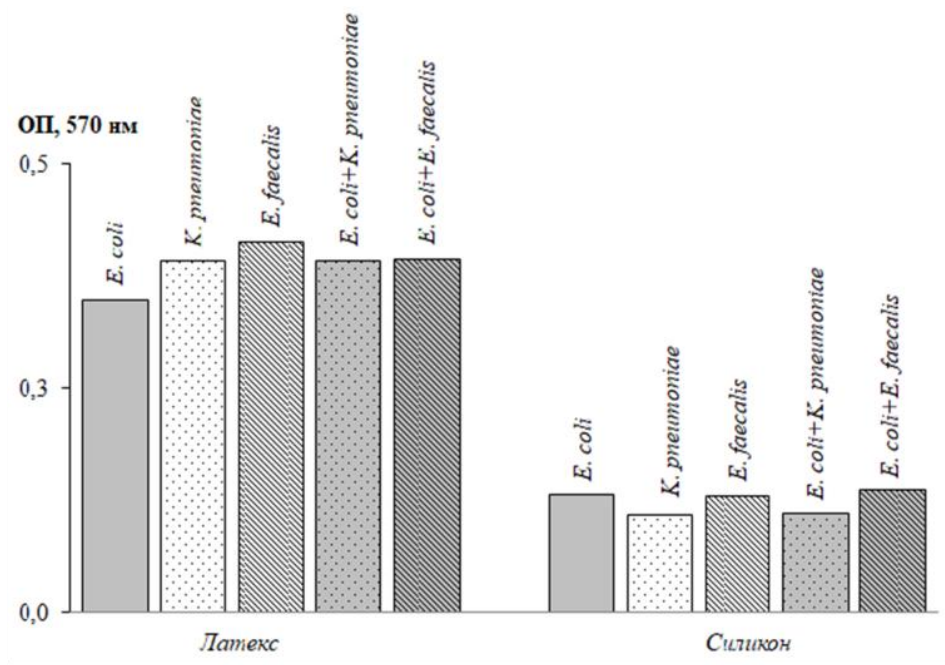

Рис. б. Биомасса моновидовых и смешанных биопленок на поверхности катетеров из латекса и силикона 
телей. Изучение механизмов адгезии, ности UPEC может быть использована формирования биопленок и оценка для разработки медицинских матевлияния различных факторов на струк- риалов, менее подверженных бактеритурную организацию прикрепленных альной колонизации, а также поиска микробных сообществ представляет эффективных способов предупреждения научную и практическую значимость. адгезии бактерий на внедренные медиИнформация о колонизационной актив- цинские устройства.

\section{Библиографический список}

1. Бухарин O.В., Грищенко В.А., Вялкова А.А. Факторы уропатогенности бактерий: роль в патогенезе и значение в диагностике пиелонефрита // Нефрология и диализ. - 2001. - Т. 3. - № 4. - С. 469-475.

2. Гизатуллина Ю.С., Кузнеиова М.В. Формирование биопленок уропатогенными штаммами Escherichia coli на различных абиотических поверхностях // Вестник Пермского университета. 2017. - № 2. - C. 185-192.

3. Жабченко И.A. Уропатогенные штаммы Escherichia coli: особенности функционирования, факторы вирулентности, значение в клинической практике // Таврический медико-биологический вестник. 2013. - Т. 16. - № 2. - Ч. 2. - С. 201-206.

4. Каримова Н.В., Гизатуллина Ю.С., Демаков В.А. Колонизационная активность уропатогенных Escherichia coli в полимикробных ассоциациях // Высокие технологии, определяющие качество жизни: материалы II Международной науч. конф. - Пермь. - 2018. - С. 221.

5. Коган М.И., Хасигов А.В., Белоусов И.И. Микробный спектр мочи при коралловидном нефролитиазе // Саратовский научно-медицинский журнал. - 2011. - Т. 7. - № 3. - С. 714-718.

6. Кузнецова М.В., Проворова С.В., Кубарев О.Г., Юдин Д.П., Каримова Н.В., Баяндина Н.В., Теплякова М.A., Демаков B.A. Сравнительная характеристика штаммов уропатогенной Escherichia coli, выделенных в условиях поликлиники и стационара // Урология. - 2018. - № 6. - С. 37-44.

7. Лагун Л.В., Жаворонок С.В. Бактериальные биопленки и их роль в инфекции мочевыводящих путей // Медицинский журнал. - 2013. - № 4. - С. 21-27.

8. Малей М. Лечение инфекций мочевыводящих путей: фокус на фторхинолоны // Медицинские аспекты здоровья мужчины. - 2015. - № 2(17). - С. 27-31.

9. Мальцев С.В., Мансурова Г.Ш. Что такое биопленка? // Природная медицина. - 2013. - № 13. - С. 86-89.

10. Немеч Е.А., Юнес Р.А., Худошин А.К., Габриэлян Н.И., Севастьянов В.И. Образование биопленок штаммами госпитальной флоры, выделенными из биологических субстратов пациентов, на поверхности материалов и изделий медицинского назначения // Вестник трансплантологии и искусственных органов. - 2013. - Т. 15. - № 4. - С. 92-97.

11. Перепанова Т.С. Значение инфекций, обусловленных образованием биопленок, в урологической практике // Эффективная фармакотерапия. Урология и нефрология. - 2013. - № 4(37). - С. 26-30.

12. Сергевнин В.И., Ключарева Н.М. Факторы риска и профилактика внутрибольничных катетерассоциированных инфекций мочевыводящих путей // Заместитель главного врача. - 2016. № 4(119). - C. 82-85.

13. Abdallah N.M.A., Elsayed S.B., Yassin M.M., El-gohary M., El-gohary G.M. Biofilm forming bacteria isolated from urinary tract infection, relation to catheterization and susceptibilityto antibiotics // Int. J. Biotechnol. Mol. Biol. Res. - 2011. - Vol. 2. - P. 172-178.

14. Balasubramanian A., Chairman K., Ranjit Singh A.J.A., Alagumuthu G. Isolation and identification of microbes from biofilm of urinary catheters and antimicrobial susceptibility evaluation // As. Pas. J. Trop. Biomed. - 2012. - Vol. 8. - P. 1780-1783.

15. Donlan R.M., Costerton J. Biofilms: Survival Mechanisms of Clinically Relevant Microorganisms // Clin. Microbiol. Rev. - 2002. - Vol. 15(2). - P. 167-193.

16. Ferrières L. Escherichia coli strains during catheter-associated biofilm formation // FEMS Imm Med Microbiol. - 2007. - Vol. 51(1). - P. 212-219.

17. Giray B., Ucar F.B., Aydemir S.S. Characterization of uropathogenic Escherichia coli strains obtained from urology outpatient clinic of Ege Medical Faculty in İzmir // Turk.J. Med. Sci. - 2012. - Vol. 42. - P. 1328-1337.

18. Grabe M., Bartoletti R., Bjerklund-Johansen T.E., Çek R.S., Pickard H.M., Tenke P., Wagenlehner F., Wullt B. Инфекции мочевыводящих путей у пациентов с почечной недостаточностью, после трансплантации почки, сахарным диабетом и иммуносупрессией. Рекомендации Европейской ассоциации урологов / Урология и нефрология. Избранные вопросы нефрологии. - 2015. - № 6. - С. 4-14.

19. Melecos M.D., Naber K.G. Complicated urinary tract infections // Int. J. Antimicrob. Agents. - 2000. Vol. 15. - P. 247-256. 
20. Nicolle L.E. Catheter associated urinary tract infections // Antimicrob. Resist. Inf. Control. - 2014. Vol. 3(23). - P. 1-8.

21. Pagedar A., Singh J., Batish V.K. Surface hydrophobicity, nutritional contents affect Staphylococcus aureus biofilms and temperature influences its survival in preformed biofilms // J. B. Microbiol. - 2010. Vol. 50. - P. 98-106.

22. Romeo T. Bacterial biofilms // In: Springer Ed. T. Romeo - Hidelberg. - 2008. - P. 295.

23. Schilling A.T. The effect of $\mathrm{pH}$ on the bacterium E. coli // California State Science Fair (2008).

24. Tenke P., Kovacs B., Jackel M., Nagy E. The role of biofilm infection in urology // World J. Urol. - 2006. Vol. 24. - P. 13-20.

\title{
UROPATHOGENIC ESCHERICHIA COLI STRAINS: BIOLOGICAL PROPERTIES AND COLONIZATION ACTIVITY
}

\author{
M.V. Kuznetsova, J.S. Gizatullina, V.A. Demakov \\ Institute of Ecology and Genetics of Microorganisms UB RAS
}

The problem of catheter-associated urinary tract infections is caused by the active colonization of embedded medical materials by bacteria and biofilm formation. The article presents the characteristics of urinary and catheter-associated nosocomial Escherichia coli (UPEC) strains. It observes biofilm formation and UPEC viability on different types of urological catheters both in monoculture, and associations in vitro. The influence of the properties of the attacked surface, as well as environmental factors, on the colonization activity of bacteria has been shown in the study.

Keywords: uropathogenic Escherichia coli, biofilms, urological catheters, microbial associations.

\section{Сведения об авторах}

Кузнецова Марина Валентиновна, доктор медицинских наук, ведущий научный сотрудник лаборатории молекулярной микробиологии и биотехнологии, Институт экологии и генетики микроорганизмов УрО РАН РАН - филиал Пермского федерального исследовательского центра УрО РАН (ИЭГМ УрО РАН), 614081, г. Пермь, ул. Голева, 13; e-mail: mar@iegm.ru

Гизатуллина Юлия Сагитовна, инженер лаборатории молекулярной микробиологии и биотехнологии, ИЭГМ УрО РАН; e-mail: gizatullina.julia@yandex.ru

Демаков Виталий Алексеевич, доктор медицинских наук, член-корреспондент РАН, профессор, заведующий лабораторией молекулярной микробиологии и биотехнологии ИЭГМ УрО РАН; e-mail: demakov@iegm.ru 